\title{
ROUTINE IDENTIFICATION OF GROUP-C STREPTOCOCCI BY MEANS OF AN AGGLUTININ (PROTECTIN) FROM THE ALBUMEN GLAND OF THE EDIBLE SNAIL, HELIX POMATIA
}

\author{
W. KöHLER*, O. ProKoP† AND O. KüHNEMUND*
}

Central Institute for Microbiology and Experimental Therapy, Jena (Academy of Sciences of the GDR **, and Institute for Forensic Medicine, Humboldt University, Berlin†, Germany, GDR

THE albumen gland of the edible snail, Helix pomatia, contains an agglutinin specific for human erythrocytes of blood-group A (Prokop, Rackwitz and Schlesinger, 1965; Prokop, Schlesinger and Rackwitz, 1965). This is one of a class of antibody-like substances, named " protectins " by Prokop, Uhlenbruck and Köhler (1968a and $b$ ), found in snails, fishes and other cold-blooded animals. The $H$. pomatia protectin is now designated anti-A $\mathrm{HP}_{\mathrm{HP}}$ (formerly anti- $\left.A_{\text {hel }}\right)$; the specificity of the reaction with it is due to the presence in the agglutinated cells of terminal non-reducing N-acetyl-D-galactosamine residues (Uhlenbruck and Prokop, 1966). This led us to expect that group-C streptococci, which have the same terminal aminosugar in their group polysaccharide, would be agglutinated by anti- $A_{H P}$. In our earlier studies (Köhler and Prokop 1967a) we obtained agglutination only with group-C streptococci and with one of two group-H streptococci.

Since 1967, anti- $\mathrm{A}_{\mathrm{HP}}$ has been used for the routine differentiation of $\beta$-haemolytic streptococci, and the results have been compared with those of grouping by the precipitation test with formamide (Fuller) extracts and by the group-specific agglutination reaction of Rosendal (1956).

\section{MATERIALS AND METHODS}

Streptococci. Altogether 4224 isolates of $\beta$-haemolytic streptococci were tested. They had been isolated from cases of scarlet fever, tonsillitis, pharyngitis, sore throat and " other infections" (wounds, otitis media, urine, etc.).

Extraction of the helix agglutinin (anti- $\left.A_{H P}\right)$. The snails were collected in May and June when they were fertile and producing eggs. The shell was opened with a pair of scissors and the large albumin gland removed. The glands were desiccated, lyophilised and ground with an electric mixer. Ten milligrams of the fine yellowish powder so obtained were suspended in $1 \mathrm{ml}$ of saline. After $30 \mathrm{~min}$., the tube was centrifuged and the supernatant used as " antiserum " in the slide-agglutination test. Crude extracts so obtained had a titre of about 160 in the slide-agglutination test; purified preparations (Kühnemund and Köhler, 1969) agglutinate group-C streptococci in dilution up to 1 in 10,240 .

The agglutination reaction. The streptococci were grown overnight in beef-heart infusion broth, centrifuged and trypsinised in a way similar to that used for T-agglutination of group-A streptococci (Williams, 1958). The agglutination reactions were performed on glass slides.

\section{RESULTS}

All 338 of the group-C streptococci, but none of the 3560 group-A, or the 262 group-G streptococci, were agglutinated by the helix protectin anti- $\mathrm{A}_{\mathbf{H P}}$ (the table). The test therefore seems to be a convenient and sensitive means of identifying group-C streptococci in material from clinical sources. The only other streptococci in this series that gave a positive reaction with anti- $\mathrm{A}_{\mathrm{HP}}$ were the four $\beta$-haemolytic members of group $\mathrm{H}$; these streptococci caused clearing around streak cultures on blood-agar plates but there was incomplete clearing around 
deep colonies. In previous studies (Köhler and Prokop, 1967a) $\alpha$-haemolytic group-H streptococci, as well as $\alpha$-haemolytic or non-haemolytic members of groups D, F, K, L, N and $\mathrm{Q}$ had given negative tests.

None of the four group-E streptococci in the present series was agglutinated by anti- $A_{H P}$. Group-E streptococci can be divided into two subgroups by the use of another protectin, anti- $E_{\mathrm{RR}}^{\text {Streptoc. }}$ obtained from the roe of roach (Rutilus rutilus). The specificity of one of these groups (" Fi ") is determined merely by L-rhamnose and that of the other (" Ut ") by Lrhamnose and $\beta$-D-glucosyl residues (Köhler, Prokop and Kühnemund, 1968). Strains of

\section{TABLE}

Slide-agglutination test with $\beta$-haemolytic streptococci and Helix pomatia protectin $\left(\right.$ anti- $\left.A_{H P}\right)$

\begin{tabular}{|c|c|c|}
\hline \multirow[b]{2}{*}{$\begin{array}{l}\text { Group of } \\
\text { streptococcus }\end{array}$} & \multicolumn{2}{|r|}{ Number of strains } \\
\hline & tested & $\begin{array}{l}\text { that gave a positive reaction } \\
\text { with anti- } \mathrm{A}_{\mathrm{HP}}\end{array}$ \\
\hline A & 3560 & 0 \\
\hline B & 17 & 0 \\
\hline C & $338^{*}$ & 338 \\
\hline D & 20 & 0 \\
\hline $\mathrm{E}$ & 4 & 0 \\
\hline $\mathrm{F}$ & 4 & 0 \\
\hline G & $262 \dagger$ & 0 \\
\hline$\vec{H}$ & 4 & 4 \\
\hline $\mathrm{K}$ & 6 & 0 \\
\hline$\stackrel{p}{\mathbf{P}}$ & 1 & 0 \\
\hline$\stackrel{\text { S }}{\text { Ungroupable }}$ & $\begin{array}{l}3 \\
5\end{array}$ & $\begin{array}{l}0 \\
0\end{array}$ \\
\hline Any & 4224 & 342 \\
\hline & & \\
\hline
\end{tabular}

* 172 grouped by precipitation and agglutination; 166 grouped by agglutination only.

$\uparrow 206$ grouped by precipitation and agglutination; 56 grouped by agglutination only.

the " Ut "-subgroup are agglutinated by anti-A $\mathrm{A}_{\mathrm{HP}}$ (Kühnemund and Köhler, 1970), but these are usually not $\beta$-haemolytic. It is unlikely, therefore, that they will cause confusion in the identification of group-C streptococci.

The only other anomalous reaction we have observed-but not in this series-was with an ungroupable streptococcus (no. 9274) that reduced and clotted 0.1 per cent. methylene blue milk, grew on 40 per cent. bile agar, reduced tellurite, split arginine and thus closely resembled Streptococcus faecalis var. zymogenes.

In tests in capillary tubes, and in agar-gel immunodiffusion tests, the formamide extracts of group-C streptococci gave a precipitate with anti- $A_{\text {HP. }}$ In the latter tests, there was a reaction of identity with the line of precipitation between the streptococcal extract and a group-C rabbit antiserum (Köhler, 1970). We did not obtain satisfactory results in ringprecipitation tests in small tubes because the formamide extracts and the albumen gland extracts mixed immediately. Lancefield extracts were not tried.

\section{Discussion}

The detection in snails and fishes of antibody-like substances that agglutinate specifically the red blood cells of different groups and also react specifically with bacteria, opened a new field of immunochemical "end grouping". Prokop, Uhlenbruck and Köhler (1968a and $b$ ) 
believe that these substances may act in nature to protect the eggs from attack by microorganisms in the environment (e.g., in soil or water). Frequently, substances with more than one immunochemical specificity are to be found in the albumen gland of snails, in the roe of fishes, and in extracts of marine sponges (Dodd, MacLennan and Hawkins, 1968; Khalap, Thompson and Gold, 1970). It is not yet known whether the different specificities reside in the same molecule, but purified preparations of $H$. pomatia anti- $\mathrm{A}_{\mathrm{HP}}$ have agglutinating activity for both red cells and the appropriate bacteria, and behave uniformly in acrylamide electrophoresis, immunodiffusion, and ultracentrifugation. However, more detailed studies are necessary in this field.

Anti-A $\mathrm{H}_{\mathrm{HP}}$ reacts with $\alpha$ - and $\beta$-N-acetyl-D-galactosamine residues in the terminal position. Group-C streptococci are also agglutinated by extracts of the albumen gland of $\mathrm{H}$. (Cepaea) hortensis (the garden snail) and seed extracts of Dolichos biflorus (Köhler and Prokop, 1967b), which react with the $\alpha$-anomer only. It can therefore be concluded that the side chains of the group-specific carbohydrate of group-C streptococci have the structure: $\mathrm{O}-\alpha-\mathrm{N}$-acetylgalactosaminyl $\rightarrow$ L-rhamnose $_{(\mathrm{n})}$ (Uhlenbruck, Pardoe and Prokop, 1970).

A second immunochemical specificity of anti- $\mathrm{A}_{\mathrm{HP}}$ is directed against the $\alpha-\mathrm{N}$-acetyl-Dglucosamine in the teichoic acid of Staphylococcus aureus (Hammerström and Kabat, 1969). We found earlier that most Staph. aureus strains are agglutinated by anti- $A_{H P}$. The immunochemical specificity responsible for the reaction with other species, especially with all 31 strains of the strains of Corynebacterium diphtheriae, including members of types gravis, mitis and intermedius (Prokop and Köhler, 1967), has not yet been studied. Extracts of $H$. pomatia also (1) react with some tumour-cells of patients not of blood-group A, probably due to change in the surface antigens of the tumour cells (Prokop et al., 1968), (2) contain a polyvalent proteinase inhibitor (Uhlenbruck, Sprenger and Ishiyama, 1971), and (3) stimulate the production of experimental granulomatous tissue (Buntrock and Schnitzler, 1971). This last property may account for the therapeutic effect of anti- $\mathrm{A}_{\mathbf{H P}}$-containing ointments on the healing of chronic ulcers of the leg (Prokop, Dietz and Köhler, 1970).

\section{SUMMARY}

A crude extract of the albumen gland of the edible snail, Helix pomatia, was used for the routine identification of group-C streptococci. The reaction is specific; all of the 338 group-C strains reacted with the extract but none of either 3560 group-A or 262 group-G strains. The test may be performed by slide-agglutination with trypsinised cells, or by capillary precipitation or agar-gel immunodiffusion tests with formamide extracts of streptococci.

\section{REFERENCES}

Buntrock, P., AND SCHNitzleR, S. 1971. Steigerung der experimentellen Granulationsgewebsbildung durch das Protectin Anti-A $\mathrm{A}_{\mathrm{HP}}$. Dte GesundhWes., 26, 1420.

Dodd, R. Y., MaclenNan, A. P., ANd Hawkins, D. C. 1968. Haemagglutinins from marine sponges. Vox Sang., 15, 386.

Hammarström, S., AND Kabat, E. A. 1969. Purification and characterization of a bloodgroup A reactive hemagglutinin from the snail Helix pomatia and a study of its combining site. Biochemistry, Easton, 8, 2696.

Khalap, S., Thompson, T. E., AND Gold, E. R. 1970. Haemagglutination and haemagglutination-inhibition reactions of extracts from snails and sponges. Agglutination of human and various animal red cells: its inhibition by sugars and aminosugars. Vox Sang., 18, 501.

KöHLER, W. 1970. Reaktionen von Mikroorganismen mit Protectinen. In Fortschritte der Hämatologie, edited by E. Perlick, W. Plenert and O. Prokop, Leipzig, vol. 1, p. 41.

KöHLER, W., AND ProKop, O. 1967a. Agglutination von Streptokokken der Gruppe C durch ein Agglutinin aus Helix pomatia. Z. ImmunForsch. Allerg. klin. Immun., 133, 50.

KöHLER, W., AND PROKOP, O. 1967b. Agglutinationsversuche an Streptokokken mit dem Phytagglutinin aus Dolichos biflorus. Z. ImmunForsch. Allerg. klin. Immun., 133, 171. 
KöHler, W., ProkoP, O., AND Kühnemund, O. 1968. Über den Nachweis eines neuen

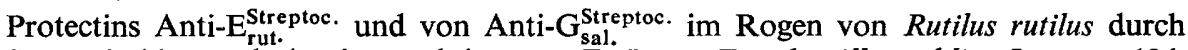
Streptokokkenagglutinationsreaktionen. Z. ImmunForsch. Allerg. klin. Immun., 134, 462.

KÜHNEMUND, O., AND KöHLER, W. 1969. Untersuchungen über die Reinigung des Protektins Anti-A $_{\text {hel }}\left(\right.$ Anti-A $\mathrm{A}_{\mathrm{HP}}$ ) aus Helix pomatia. Experientia, 25, 1137.

KÜHNEMUND, O., AND KöHLER, W. 1970. Streptokokkenagglutinierende Protectine aus Helix aspersa, Helix lucorum und Rapana thomasiana thomasiana Crosse. Z. ImmunForsch. Allerg. klin. Immun., 139, 398.

Prokop, O., Dietz, O., AND KöHLER, W. 1970. Die therapeutische Verwendung von AntiA HP zur Behandlung staphylogener Hauterkrankungen infolge der Affinität des heterophilen Anti-A $\mathrm{HP}_{\mathrm{HP}}$ Agglutinins zur Teichonsäure. Acta biol. med. germ., 24, K19.

Prokop, O., GrafFi, A., HoffManN, F., AND Schnitzler, S. 1968. Untersuchungen über die Nachweisbarkeit von N-Azetyl-D-Galaktosamin bei menschlichen Tumoren und eventuelle medizinische Konsequenzen aus den Befunden. Dte GesundhWes., 23, 1926.

ProKoP, O., AND KöHLER, W. 1967. Agglutinationsreaktionen von Mikroorganismen mit

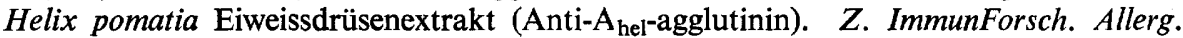
klin. Immun., 133, 176.

Prokop, O., RaCKwITZ, A., AND SChlesinger, D. 1965. A “ new" human blood group receptor $\mathrm{A}_{\text {hel }}$ tested with saline extracts from Helix hortensis (garden snail). J. Forens. Med. 12, 108.

Prokop, O., SChlesinger, D., AND RaCKwItZ, A. 1965. Über eine thermostabile “ antibodylike substance" (Anti-A hel) bei Helix pomatia und deren Herkunft. Z. ImmunForsch. Allerg. klin. Immun., 129, 402.

Prokop, O., Uhlendruck, G., AND KöHLER, W. 1968a. Protectine, eine neue Klasse antikörperähnlicher Verbindungen. Dte GesundhWes., $23,318$.

Prokop, O., UhlenBruck, G., AND KöHLER, W. $1968 \mathrm{~b}$. A new source of antibody-like substances having anti-blood group specificity. A discussion on the specificity of helix agglutinins. Vox sang., 14, 321.

ROSENDAL, KIRSTEN 1956. Grouping of hemolytic streptococci belonging to groups A, C, and $\mathrm{G}$. A comparison between the results obtained by precipitation and by slide agglutination. Acta path: microbiol. scand., 39, 127.

Uhlenbruck, G., PARdoe, Grace I., AND Prokop, O. 1970. Untersuchungen zur Spezifität der Helixagglutinine. In Fortschritte der Hämatologie, edited by E. Perlick, W. Plenert and O. Prokop, Leipzig, vol. 1, p. 71.

Uhlenbruck, G., AND Prokop, O. 1966. An agglutinin from Helix pomatia which reacts with terminal N-acetyl-D-galactosamine. Vox. sang., 11, 519.

Uhlenbruck, G., Sprenger, I., AND Ishryama, I. 1971. A new polyvalent proteinaseinhibitor occurring in the albumin gland of Helix pomatia. Z. klin. Chem. klin. Biochem., 9, 361 .

Williams, R. E. O. 1958. Laboratory diagnosis of streptococcal infections. Bull. Wld Hlth Org., 19, 153.

Vol. 5, No. 4, November 1972, was issued on 8.12.72. 